Gut, 1981, 22, 158-167

Progressis report

\title{
The pancreas as a single organ: the influence of the endocrine upon the exocrine part of the gland
}

It is tacitly assumed that the endocrine and exocrine parts of the pancreas are independent of each other, almost as though they were anatomically related by some sort of celestial coincidence. What we hope to suggest in this paper is that the two components are functionally related, and that the endocrine gland exerts a profound effect upon the digestive activities of the organ.

\section{Vascular anatomy of the pancreas}

In 1882, Kühne and $\mathrm{Lea}^{1}$ noticed that the pancreas of the living rabbit contained many discrete vascular regions, and they compared the vessels of these regions with glomerular tufts. It was not until 1893 that Laguesse ${ }^{2}$ suggested that the vascular regions might be secreting something into the blood which prevented the normal animal from becoming diabetic. He suggested that the vascular areas be called the islets of Langerhans, in memory of their discoverer. ${ }^{3}$

Subsequently, several authors have compared the morphology of endocrine and exocrine vessels and have demonstrated that the capillaries of the islets are wider and more densely arranged than are the exocrine capillaries surrounding the islet. ${ }^{4-8}$ These authors, with one exception, noticed that capillary connections existed between the vessels of the islets and the capillaries of the exocrine gland. The presence of these capillary connections is central to the theme of this review.

As islets receive their blood supply via short arterioles ${ }^{6}{ }^{7}$ and as the capillaries of the islets are often wider than those of the exocrine tissue, it is reasonable to assume that the capillary pressure is higher in the islet vessels than in the adjacent exocrine vessels. So where islet-exocrine connections exist the direction of flow should be predominantly outwards. This centrifugal flow has been demonstrated by cinematography in the pancreas of the living rabbit. ${ }^{10}$ The frequency of these endocrine-exocrine connecting vessels (Figure) has been shown by several authors, using a variety of injection techniques. ${ }^{11-15}$ Two authors have suggested that the centrifugal flow from endocrine to exocrine pancreas plays a significant role in the metabolic activity of the exocrine pancreas. ${ }^{16} 17$ This review considers the evidence for this relationship, which depends upon the presence of very high concentrations of hormones in the capillaries leaving the islet under different metabolic conditions.

\section{Effect of insulin on exocrine function}

Insulin increases the uptake and incorporation of glucose and amino acids into most metabolically active tissues. ${ }^{18}$ As the exocrine pancreas has a very 


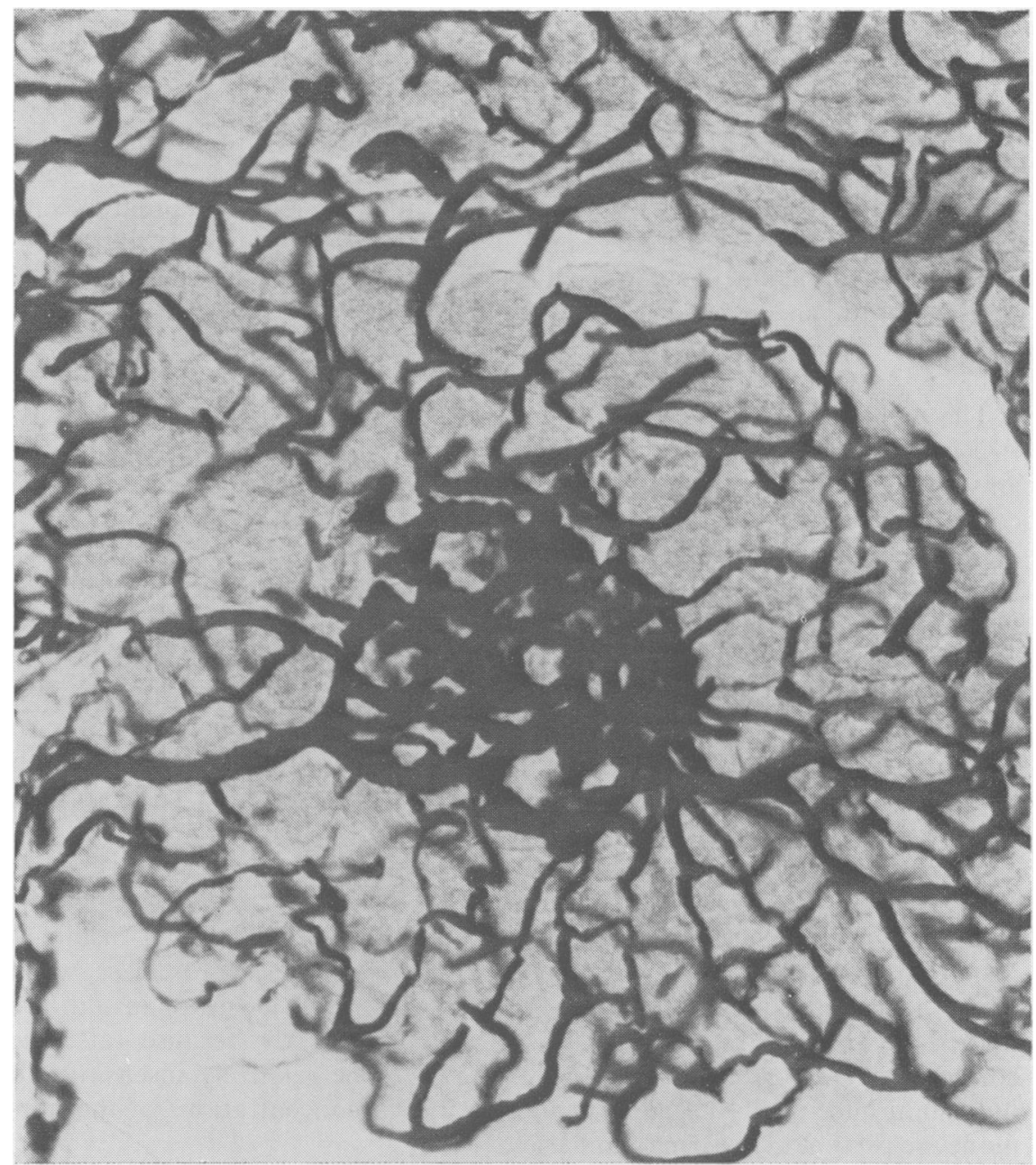

Figure A section (60 $\mu \mathrm{m})$ of cat pancreas that has been injected with Berlin blue via an artery. An islet is in the centre of the picture, and many capilliary connections connect the islet vasculature with that of the exocrine pancreas. The large vessel is probably an arteriole supplying the islet whose diameter is about $150 \mathrm{\mu m}$.

high rate of protein synthesis, ${ }^{19}$ it seems reasonable to suggest that the synthesis of its protein might be controlled by the level of insulin in the capillaries leaving the islets and supplying the exocrine tissue. Damage to the B cells by alloxan profoundly diminishes the synthesis and release of amylase from the exocrine pancreas of the rat. ${ }^{2021}$ The synthesis and release of amylase can be restored to normal by the injection of insulin. In the exocrine cells the incorporation of tritium-labelled leucine into amylase can be increased by insulin and, by using actinomycin D, it was found that insulin stimulates the synthesis of amylase messenger-RNA, and that streptozotocin (a more specific anti-B-cell agent than alloxan) caused a marked diminution of amylase activity in the exocrine pancreas. ${ }^{21}$ Interestingly, insulin seems to affect only the amylase component of the zymogen granules. Thus there is an increase in amylase content, but a decrease in chymotrypsinogen and lipase 
in the exocrine pancreas of the rat after the chronic rise in insulin levels produced by glucose infusion. No change in the proteolytic activity of the pancreatic juice was demonstrated after treatment with alloxan or streptozotocin. ${ }^{22}$ It is relevant that the commonest abnormality in the pancreatic juice of insulin-dependent diabetics is a low output of amylase. ${ }^{23} \mathbf{2 4}$ It has also been found that insulin-requiring diabetics, in response to a standard secretin-pancreozymin test, secreted significantly less bicarbonate in their pancreatic juice than control subjects. It is generally believed that the influence of insulin on amylase synthesis is not the result of hypoglycaemia induced by insulin, though an interesting case for such a relationship has been made out. ${ }^{25}$

The presence or absence of insulin is crucial when pancreozymin (CCKPZ) is used as a stimulus for amylase output. Thus pancreozymin-induced amylase release is significantly reduced in streptozotocin-diabetic rats when compared with controls; treatment of the diabetic rats with insulin for a week increased the pancreozymin-induced amylase output so that it was almost back to normal levels. ${ }^{26}$ Similarly, an estimate has been made of total protein content in the pancreatic juice of the rat. ${ }^{27}$ Pancreozymin caused protein release in fasting rats, an effect that was potentiated by giving insulin an hour before the pancreozymin. However, when insulin was accompanied by a glucose infusion, the potentiating effect of insulin on the secretion of protein was not reduced. Thus the influence of insulin on protein secretion was not secondary to the hypoglycaemic effect of the hormone. ${ }^{27}$

There are two general points worth making about these experiments: (1) they were all done on animals with an intact pancreatic circulation: a functioning circulation seems essential to show these effects of insulinfor example, insulin had no effect on amylase synthesis or release when tested on isolated pieces of mouse pancreas $;^{28}(2)$ high doses of insulin are needed to elicit a response. This is reasonable-partly because rats (the commonest experimental animal) are known to be relatively insensitive to ox insulin and, partly because, in life, very high concentrations of the hormone are present in exocrine capillaries.

Other evidence that blood from the islets influences the rest of the gland comes from human disease. Thus the exocrine pancreas of insulin-dependent human diabetics is much smaller than normal. ${ }^{2930}$ Furthermore, when diabetic patients are tested for exocrine pancreatic function, they show a diminished response, and the response diminishes with the duration of the disease. ${ }^{23}{ }^{24}$ So it seems that insulin may be necessary both for the synthesis of pancreatic enzymes and for maintaining the size of the exocrine part of the gland.

An early intimation that exocrine pancreatic growth might be related to endocrine tissue came from Henry Dale in $1904 .{ }^{31} \mathrm{He}$ noticed, in the toad, that more mitoses were present in the neighbourhood of islets than elsewhere. The number of mitoses normally observed in the exocrine pancreas is very low. It was therefore surprising that administration of alloxan to the rat $^{32}$ resulted in a marked increase of mitoses in the exocrine cells, the phenomenon reaching a maximum at 17 hours and being over by 24 hours. The initial effect of alloxan is to cause release of insulin from B cells, and it seems reasonable that this release of insulin was responsible for the cell divisions. 
Another piece of evidence suggesting that islets stimulate exocrine growth comes from experiments in which $\mathbf{H}^{3}$-thymidine incorporation into DNA was followed in neonatal rats. ${ }^{33}$ The labelled nucleoside was injected into rats in the first three days of life, and the presence of the label in the exocrine cells in successive weeks was determined autoradiographically. It was found that in the first few days after injection there was relatively more thymidine in the peri-insular cells than in the distant ones; but after 11 days the distant acini contained more label than the peri-insular acini. As the main reason for the dilution of label is replication of DNA, it is likely that the cells of the peri-insular acini divide more frequently than the distal ones. ${ }^{33}$ The most obvious explanation for this is that there is a higher concentration of insulin in those acini closest to islets. This subject is discussed again under 'the halo phenomenon'.

\section{Effect of glucagon on exocrine function}

Pancreatic glucagon exerts an inhibitory effect on the secretion of the exocrine pancreas. In early experiments with glucagon, single injections of the hormone were given to anaesthetised dogs that had been fasted for an unspecified time. Pancreatic secretion was produced by infusing secretin, and subsequent injections of glucagon inhibited this secretion, the effect of a single injection of glucagon often lasting up to two hours. ${ }^{34}$ This inhibition might have been secondary to the hyperglycaemia that glucagon causes. However, the injection of glucose alone did not modify the secretion of pancreatic juice. ${ }^{34}$

When glucagon is injected into rats over a period of three weeks the exocrine pancreas atrophies ${ }^{35-37}$ and the zymogen granules disappear. It was found that 18 hours after the injection of $0.9 \mathrm{mg}$ glucagon (in corn oil) into rats the exocrine pancreas lost $90 \%$ of its zymogen granules. ${ }^{38}$ It is not clear from this work whether glucagon inhibits synthesis or stimulates enzyme release, but subsequent experiments have suggested that it does both. In conscious fasting dogs, infusion of glucagon inhibited enzyme release, but made little difference to the volume or to the bicarbonate concentration of the juice. ${ }^{39}$ As this inhibitory effect of glucagon can be seen with doses of the hormone as low as $0.2 \mu \mathrm{g} / \mathrm{kg}$ body weight, the authors suggest that levels are 'physiological' ${ }^{39}$ But, as in normal life glucagon reaching the exocrine pancreas via the islet-exocrine connections is at a far higher concentration than that which would be produced by venous infusion of the hormone, the concern over what levels are 'physiological' is misplaced. In extending these experiments to fasting humans, it was shown that glucagon decreased the protein content and the volume of pancreatic secretion, but not the bicarbonate content. ${ }^{40}$ The earliest effect of a glucagon injection is often a stimulation of exocrine secretion ${ }^{34} \mathbf{4 0}$ and this may be related to the degranulation of the exocrine gland which is seen after protracted administration of the hormone. Furthermore, there was no correlation between hyperglycaemia and pancreatic secretion. However, working with conscious fasting dogs, it was shown that glucagon caused a striking inhibition of both volume and protein content of pancreatic juice; this effect could be mimicked by infusing glucose, an observation which has not been confirmed. ${ }^{41}$

The effect of glucagon on the exocrine pancreas varies with the state of nutrition of the animal. Thus, in the rat, glucagon decreased the volume 
and the content of bicarbonate and of protein in pancreatic juice when the animal was fasting but when the glucagon was given to the fed animal it produced an increase both in the volume and in the bicarbonate content of pancreatic juice. ${ }^{42}$ This increase in volume and bicarbonate content (but not in enzymes) is more reminiscent of the effect of secretin, and it has not escaped the eye of many authors that the structure of glucagon is very similar to that of secretin, $50 \%$ of the two peptides' amino acids being identical. Yet in most of the experiments noted the two hormones exert their effect on two quite separate pancreatic secretory functions. Thus secretin usually stimulates the secretion of bicarbonate and water (probably from the centro-acinar and duct cells), while glucagon inhibits the synthesis and release of protein by the acinar cells. So it is possible that glucagon acts in a stimulatory (secretin-like) way in the fed state and in an inhibitory way during fasting. Glucagon was found to have a secretin-like effect on fed dogs and a dose of $5-20 \mu \mathrm{g} / \mathrm{kg}$ increased the flow of pancreatic juice without altering the protein concentration. ${ }^{43}$ Bicarbonate secretion was not measured.

Glucagon would reach high concentrations in the blood leaving the islets in two circumstances: (1) immediately after a protein-rich meal, and (2) during starvation. How could these effects be integrated with what is known of the influences of glucagon on the exocrine pancreas? A paper of great ingenuity ${ }^{44}$ throws some light on this. When, in man, short $(20 \mathrm{~cm})$ segments of duodenum were perfused with solutions of amino acids, CCK-PZ was released, and trypsin was secreted by the exocrine pancreas. This secretion was not accompanied by an increase of glucagon or of $\alpha$-amino nitrogen in the plasma. However, when the whole of the duodenum and jejunum were perfused with the amino acids, CCK-PZ and trypsin production were actually less than with the duodenal perfusion. Furthermore, plasma levels of glucagon and of $\alpha$-amino nitrogen were significantly raised. These authors propose that the raised levels of glucagon (seen after the perfusion of the whole bowel with amino acids) either inhibits the release of CCK-PZ, or interferes with its effect on the exocrine pancreas. These findings in man are consistent with the experiments described earlier in which glucagon was shown to inhibit output by the gland.

Many of these observations on glucagon can be integrated into a homoeostatic scheme-a scheme that would result in the economical metering-out of digestive enzymes by the exocrine pancreas. Thus, when protein digestion reached a certain level, plasma amino acids would rise, glucagon would be released from the islets into the exocrine gland, and this, in turn, would inhibit enzyme release from the gland. This would slow down the breakdown of protein in the lumen of the gut and so diminish the absorption of amino acids. We have already seen that glucagon inhibits both the synthesis and release of zymogen granules. Thus, during fasting, when plasma levels of pancreatic glucagon rise, the synthesis and release of zymogen granules would be progressively diminished. This seems an admirable piece of parsimony.

It has been suggested that over-secretion of glucagon plays a significant role in human insulin-requiring ('juvenile') diabetes. ${ }^{45}$ As high concentrations of glucagon cause the exocrine pancreas to atrophy, there might be two reasons for the atrophy of the exocrine pancreas that is found in insulinrequiring diabetics: (1) undersecretion of insulin, and (2) oversecretion of glucagon. 


\section{Influence of somatostatin on exocrine function}

Somatostatin is a third hormone secreted by the islets of Langerhans. Produced by $A_{1}$ (D) cells, the hormone has been shown to have inhibitory effects on many glands, including the adenohypophysis, the $\mathrm{A}_{2}$ and $\mathrm{B}$ cells in islets, and several endocrine cells in the gut. We shall review its effects on the exocrine pancreas.

Infusion of somatostatin into dogs inhibits secretin-induced bicarbonate secretion, but somatostatin does not inhibit the enzyme release produced by infusing CCK-PZ. ${ }^{46}$ (The reader may recall that the inhibitory effect of glucagon on the exocrine pancreas is predominantly on the secretion of enzymes brought about by CCK-PZ, which is different from the effect of somatostatin). The inhibitory effect of somatostatin on the exocrine pancreas is so powerful that the infusion of $100 \mu \mathrm{g}$ into dogs completely abolishes the production of pancreatic juice in response to a meat meal. ${ }^{47}$ This abolition occurs partly because somatostatin inhibits the actual release of secretin and CCK-PZ from the small intestine. ${ }^{48}$

Somatostatin, like glucagon, constricts mesenteric vessels, ${ }^{49}$ so that some of the inhibitory effects described might be due to vasoconstriction in the exocrine pancreas. Recently, a group of patients has been described with somatostatin-secreting tumours of the pancreas. ${ }^{50-53}$ Steatorrhoea is a common feature of this syndrome, as might be expected, because of the inhibitory influence of somatostatin on the exocrine function of the pancreas. However, somatostatin also has many effects on the bowel, including inhibition of the release of secretin and CCK-PZ as well as the inhibition of absorption of nutrients from the intestine. So inhibition of exocrine pancreatic secretion may be only one of several possible causes of the steatorrhoea which is associated with somatostatinomas.

\section{Influence of pancreatic polypeptide on endocrine function}

Pancreatic polypeptide (PP) is a recently described hormone secreted by both endocrine and exocrine pancreas. It was first demonstrated in the bird ${ }^{55}$ and subsequently in the human. ${ }^{55}$ The hormone is released by a very wide range of nutrients taken by mouth. It has no effect on endocrine function, but is a powerful inhibitor of the exocrine gland-especially on the secretion of bicarbonate and trypsin.

Without knowing more of the physiology of PP, this inhibition remains an enigma. What can be the role of a hormone-whose release is stimulated by food in the gut-that actually inhibits exocrine pancreatic secretion?

\section{'Halo' phenomenon around islets}

It was noticed by Jarotsky in $1899^{57}$ that those exocrine cells adjacent to islets stained more strongly than more distant exocrine cells, which gave the appearance of a halo around each islet. In a study of exocrine cells, it was found that the cells closest to the islets ('juxta-insular') were in fact quantitatively different from those in the exocrine tissue further away from the islets. For example, the mean area of the nuclei in juxta-insular cells was $50.6 \pm 0.8 \mu \mathrm{m}^{2}$ (SEM) and nuclei far from islets $36.4 \pm 1.8 \mu \mathrm{m}^{2}(\mathrm{P}<0.001){ }^{33}$ It was proposed that the difference between the two classes of cells was a 
consequence of the high concentration of insulin in the capillaries leaving the islets. In genetically obese hyperglycaemic mice (which have very large islets and hyperinsulinaemia) the nuclear size of juxta-insular exocrine cells was even larger $\left(57 \cdot 8 \mu \mathrm{m}^{2} \pm 2 \cdot 2\right)$, although the nuclear size of the distant cells was much the same as that in distant cells of normal mice. Similar measurements in the rat pancreas confirmed these findings $;^{58}$ the cells close to islets contained more zymogen granules than distant cells. Injection of alloxan, which rendered the rats diabetic, abolished the haloes (this can be seen in spite of the partial destruction of the islets). This abolition was not a direct effect of alloxan on the exocrine pancreas. ${ }^{58}$

It is interesting to note that there are two types of islets in birds, light and dark, only one of which - the 'light' type-secretes insulin. This type is surrounded by exocrine cells whose nuclei are significantly larger than the nuclei of exocrine cells adjacent to the dark islets - that is, ones that do not secrete insulin. ${ }^{1659}$ When sections of duck pancreas are stained for cholinesterase there is a noticeable zone of cholinesterase-positive material round the light, insulin-secreting islets, and none surrounding the dark islets which do not secrete insulin (personal observations).

It is tempting to ascribe the halo phenomenon to the influence of a high concentration of insulin in the vessels leaving the islet, and many of the observations which we have quoted support this idea. However, the concentration of amylase, lipase, and chymotrypsinogen is higher in distant endocrine cells than in cells adjacent to islets. ${ }^{60}$ This supports the general hypothesis that the secretions of the islets influence the exocrine pancreas, although in what seems an unexpected way. Another observation which supports the islet-exocrine hypothesis is that the treatment of rats with streptozotocin shows that there is an almost total loss of amylase in the exocrine cells both close to, and far from, the islets. ${ }^{60}$ What is not clear is why in normal animals enzymes are at lower concentrations in the exocrine cells near islets than in the cells far from islets. It has been suggested that somatostatin and/or glucagon leaving the islets inhibits both the synthesis and release of enzymes, so producing the low concentrations of enzyme found around the islets. We have mentioned this in the section on somatostatin.

The evidence we have cited suggests that the secretions of the islets of

Table Effect of islet hormones on exocrine pancreas

\begin{tabular}{|c|c|c|}
\hline Islet hormone & Effect on function of exocrine pancreas & $\begin{array}{l}\text { Nutritional status } \\
\text { of animals }\end{array}$ \\
\hline Insulin & $\begin{array}{l}\text { Increases uptake of amino acids } \\
\text { Increases synthesis of amylase (independently } \\
\text { from effect on amino acids) } \\
\text { Increases cell division } \\
\text { Is necessary for normal release of bicarbonate }\end{array}$ & $\begin{array}{l}\text { Fed } \\
\text { Fed } \\
\text { Fed } \\
\text { Fed }\end{array}$ \\
\hline Glucagon & $\begin{array}{l}\text { Inhibits synthesis of enzymes } \\
\text { Inhibits release of enzymes }{ }^{3940} 47 \\
\text { Stimulates release of bicarbonate }\end{array}$ & $\begin{array}{l}\text { Fasted } \\
\text { Fasted } \\
\text { Fed }\end{array}$ \\
\hline Somatostatin & Inhibits the production of pancreatic juice ${ }^{47}$ & Fed \\
\hline $\begin{array}{l}\text { Pancreatic } \\
\text { polypeptide }\end{array}$ & Inhibits release of enzymes & Fed \\
\hline
\end{tabular}


Langerhans are essential for the proper functioning of the exocrine pancreas. The Table summarises the way in which the known secretions of the exocrine pancreas are modified by the secretions of the islets.

PMD held an Emeritus Fellowship from the Leverhulme Trust while this work was being done, for which he is most grateful.

\section{J R HENDERSON, P M DANIEL, AND P A FRASER}

Department of Physiology, St. George's Hospital Medical School, London, the Department of Physiology and Surgical Science, Royal College of Surgeons of England, Lincoln's Inn Fields, London, Department of Biochemistry, St. Thomas's Hospital Medical School, London and the Department of Physiologv, King's College, Strand, London

Received for publication 22 September 1980

\section{References}

${ }^{1}$ Kühne W, Lea AS. Beobachtungen über die Absonderung des Pankreas. Untersuchungen aus dem Physiologischen Institute der Universität Heidelberg 1882; 2: 448-87.

${ }^{2}$ Laguesse ME. Sur la formation des ilôts de Langerhans dans le pancréas. CR Soc Biol (Paris) 1893; 45: 819-20.

${ }^{3}$ Langerhans P. Beitrage zur Mikroskopischen Anatomie der Bauchspeicheldrüse. MD Thesis Wilhelm Freidrich Universität Berlin 1869. Translated by H. Morrison. In: Bull Inst Hist Med 1937; 5: 285-97.

${ }^{4}$ Opie EL. Diseases of the pancreas. Philadelphia: Lippincott, 1910.

${ }^{5}$ Berg BN. A study of the islands of Langerhans in vivo with observations on the circulation. Am J Physiol 1930; 95: 186-9.

${ }^{6}$ Wharton GK. The blood supply of the pancreas, with special reference to that of the islands of Langerhans. Anat Rec 1932; 53:55-81.

${ }^{7}$ Brunfeldt K, Hunhammar K, Skouby AP. Studies on the vascular system of the islets of Langerhans in mice. Acta Endocrinol (Kbh) 1958; 29: 473-80.

${ }^{8}$ McCuskey RS, Chapman TM. Microscopy of the living pancreas in situ. Am J Anat 1969; 126: 395-407.

${ }^{9}$ Fraser PA, Henderson JR. The serial arrangement of endocrine and exocrine capillaries in the rabbit pancreas observed in vivo. J Physiol (Lond) 1979; 292: 4P.

${ }^{10}$ Fraser PA, Henderson JR. The arrangement of endocrine and exocrine pancreatic microcirculation observed in the living rabbit. $Q J$ Exp Physiol 1980, 65: 151-8.

${ }^{11}$ Fujita T. Insulo-acinar portal system in the horse pancreas. Arch Histol Japon 1973; 35: 161-71.

${ }^{12}$ Fujita T, Yanatori Y, Murakami T. Insulo-acinar axis, its vascular basis and its functional and morphological changes caused by $\mathrm{CCK}-\mathrm{PZ}$ and caerulein In: Fujita T, ed Endocrine gut and pancreas Elsevier: Amsterdam. 1976; pp. 347-57.

${ }^{13}$ Daniel PM, Henderson JR. Circulation in the islets of Langerhans. $J$ Physiol (Lond) 1978; 275: 10-11P.

${ }^{14}$ Henderson JR, Daniel PM. Portal circulations and their relation to countercurrent systems. Q J exp Physiol 1978; 63: 355-69.

${ }^{15}$ Henderson JR, Daniel PM. A comparative study of the portal vessels connecting the endocrine and exocrine pancreas, with a discussion of some functional implications. $Q$ J exp Physiol 1979; 64: 267-75.

${ }^{16}$ Ferner H. Die Dissemination der Hodenzwischenzellen und der Langerhansschen Inseln als functionelles Prinzip für die Samenkanälchen und das exokrine Pankreas. Z Zellforsch Mikrosk Anat (Berlin) 1957; 63: 35-52.

${ }^{17}$ Henderson JR. Why are the islets of Langerhans? Lancet $1969 ; 2: 469-70$.

${ }^{18}$ Hansson E. The formation of pancreatic juice proteins studied with labelled amino acids. Acta Physiol Scand 1959; 46: Suppl. 161, 42-9.

${ }^{19}$ Webster PD III, Black O Jr, Mainz DL, Singh M. Pancreatic acinar cell metabolism and function. Gastroenterology 1977; 73: 1434-49. 
${ }^{20}$ Palla JC, Abdeljlil AB, Desnuelle P. Action de l'insuline sur la biosynthèse de l'amylase et de quelques autres enzymes du pancréas du rat. Biochim Biophys Acta 1968; 158: 25-35.

${ }^{21}$ Söling HD, Unger KO. The role of insulin in the regulation of $\alpha$-amylase synthesis in the rat pancreas. Eur J Clin Invest 1972; 2 : 199-212.

${ }^{22}$ Adler G. Kern HF. Regulation of exocrine pancreatic secretory process by insulin in vivo. Hormone Metabol Res (Stutt) 1975; 7: 290-6.

${ }^{23}$ Chey WY, Shay H, Shuman CR. External pancreatic secretion in diabetes mellitus. Ann Intern Med 1963; 59: 812-21.

${ }^{24}$ Frier BM, Saunders JHB, Wormsley KG, Bouchier IAD. Exocrine pancreatic function in juvenile-onset diabetes mellitus. Gut 1976; 17: 685-91.

${ }^{25}$ Couture Y, Dunnigan J, Morisset J. Stimulation of pancreatic amylase secretion and protein synthesis by insulin. Scand J Gastroenterol 1972; 7: 257-63.

${ }^{26}$ Ohara $\mathrm{H}$. Clinical and experimental studies on the entero-insular and insulo-acinar correlations. In: Fujita T, ed Endocrine gut and pancreas. Amsterdam: Elsevier, 1976: 321-33.

${ }^{27}$ Kanno T, Ueda N, Saito A. Insulo-acinar axis: a possible role of insulin potentiating the effects of pancreozymin in the pancreatic acinar cell. In: Fujita, ed. Endocrine gut and pancreas. Amsterdam: Elsevier, 1976: 335-345.

${ }^{28}$ Danielsson $\AA$, Sehlin J. Transport and oxidation of amino acids and glucose in the isolated exocrine mouse pancreas: effects of insulin and pancreozymin. Acta Physiol Scand 1974; 91: 557-65.

${ }^{29}$ Maclean N, Ogilvie RF. Quantitative estimation of pancreatic islet tissue in diabetic subjects. Diabetes $1955 ; 4: 367-76$.

${ }^{30}$ Vartiainen I. Studien über den Diabetes mellitus in Finnland. Acta Med Scand 1944; 118: $538-74$.

${ }^{31}$ Dale HH. On the 'islets of Langerhans' in the pancreas. Philos Trans $R$ Soc Lond Biol 1904; 197: 25-46.

${ }^{32}$ Duff GL, Starr H. Experimental alloxan diabetes in hooded rats. Proc Soc Exp Biol Med 1944; 57: 280-2.

${ }^{33}$ Hellman B, Wallgren A, Petersson B. Cytological characteristics of the exocrine pancreatic cells with regard to their position in relation to the islets of Langerhans. Acta Endocrinol $(K b h) 1962 ; 39: 465-73$.

${ }^{34}$ Necheles H. Effects of glucagon on external secretion of the pancreas. Am J Physiol 1957; 191 : 595-7.

${ }^{35}$ Salter JM, Davidson IWF, Best $\mathrm{CH}$. The pathologic effects of large amounts of glucagon. Diabetes 1957; 6: 248-52.

${ }^{36}$ Lazarus SS, Volk BW. The effect of protracted glucagon administration on blood glucose and on pancreatic morphology. Endocrinology 1958; 63: 359-71.

${ }^{37}$ Cameron JM, Melrose AG. (1962). Changes in liver, pancreatic and stomach morphology following chronic glucagon administration in guinea-pigs. Br J exp Path. 1962; 43: 384-6.

${ }^{38}$ Jarrett L, Lacy PE. Effect of glucagon on the acinar portion of the pancreas. Endocrinology 1962; 70: 867-73.

${ }^{39}$ Dyck WP, Rudick J, Hoexter B, Janowitz HD. Influence of glucagon on pancreatic exocrine secretion. Gastroenterology 1969; 56: 531-9.

${ }^{40}$ Dyck WP. Texter EC, Lasater JM, Hightower NC. Influence of glucagon on pancreatic exocrine secretion in man. Gastroenterology 1970; 58: 532-9.

${ }^{41}$ Nakajima S, Magee DF. Inhibition of exocrine pancreatic secretion by glucagon and Dglucose given intravenously. Can J Physiol Pharmacol 1970; 48: 299-305.

${ }^{42}$ Shaw HM, Heath TJ. The effect of glucagon on the formation of pancreatic juice and bile in the rat. Can J Physiol Pharmacol 1973; 51:1-5.

${ }^{43}$ Fujita $T$, Watanabe $Y$. The effects of islet hormones upon the exocrine pancreas. In: Fujita T, ed. Gastro-entero-pancreatic endocrine system: a cell biological approach. Ijaku Shoin: Tokyo. 1976: pp. 164-73.

${ }^{44}$ DiMagno EP, Go VLW, Summerskill WHJ. Intraluminal and postabsorptive effects of amino acids on pancreatic enzyme secretion. J Lab Clin Med (St Louis.) 1973; 82: 241-8.

${ }^{45}$ Unger RH, Raskin P, Srikaut CB, Orci L. Glucagon and the A cells. Rec Prog Horm Res (New York) 1977; 33: 477-517.

${ }^{46}$ Konturek SJ, Tasler J, Obtulowicz W, Coy DH, Schally AV. Effect of growth hormone- 
release inhibiting hormone on hormones stimulating exocrine pancreatic secretion. J Clin Invest 1976; 58: 1-6.

${ }^{47}$ Wilson RM, Boden G, Shore LS, Essa-Koumar N. Effect of somatostatin on mealstimulated pancreatic exocrine secretion in dogs. Diabetes 1977; 26: 7-10.

${ }^{48}$ Boden G, Sivitz MC, Owen OE, Essa-Koumar N, Landor JH. Somatostatin suppresses secretin and pancreatic exocrine secretion. Science 1975; 190: 163-5.

${ }^{49}$ Pawlik W, Shepherd AP, Jacobson ED. Effects of vasoactive agents on intestinal oxygen consumption and blood flow in dogs. J clin Invest 1975; 56: 484-90.

${ }^{50}$ Larsson LI, Hirsch MA, Holst JJ et al. Pancreatic somatostatinoma. Clinical features and physiological implications. Lancet 1977; 1: 666-8.

${ }^{51}$ Ganda OP, Weir GC, Soeldner JS et al. 'Somatostatinoma'; a somatostatin-containing tumor of the endocrine pancreas. $N$ Engl J Med 1977; 296: 963-7.

${ }^{52}$ Unger RH. Somatostatinoma. N Engl J Med 1977; 296: 998-1000.

${ }^{53} \mathrm{Kreijs}$ GJ, Orci L, Conlon MJ et al. Somatostatinoma syndrome: biochemical, morphologic and clinical features. N Engl J Med 1979; 301 : 285-92.

${ }^{54} \mathrm{Kimmel}$ JR, Pollock HG, Hazelwood RL. Isolation and characterization of chicken insulin. Endocrinology 1968; 83: 1323-30.

${ }^{55} \mathrm{Kimmel}$ JR, Pollock HG, Hayden LJ. Spectrum effects of a new polypeptide (third hormone?) isolated from the chicken pancreas. Gen Comp Endocr (New York) 1973; 21: 485-97.

${ }^{56}$ Larsson LI, Sundler F, Håkanson R. Pancreatic polypeptide-a postulated new hormone: identification of its cellular storage site by light and microscopic immunocytochemistry. Diabetologia 1976; 12: 211-26.

${ }^{57}$ Jarotsky AJ. Ueber die Veränderungen in der Grösse und im Bau der Pankreaszellen bei einigen Arten der Inanition. Virchow's Arch 1899; 155: 409-50.

${ }^{58} \mathrm{Kramer}$ MF, Tan HT. The peri-insular acini of the pancreas of the rat. $Z$ Zellforsch Mikros Anat (Berlin) 1968; 86: 163-70.

${ }^{59}$ Wallgren A, Hellman B. Influence of the islet A and B cells on the exocrine pancreatic tissue in the duck. Acta Anat (Basel) 1962; 48: 137-41.

${ }^{60}$ Malaisse-Lagae F, Ravazzola M, Robberecht P. et al. Hydrolases content in peri-insular and tele-insular exocrine pancreas. In: Fujita T, ed Endocrine Gut and Pancreas. Amsterdam: Elsevier, 1976. 313-20.

\section{Note added in proof}

Since writing this paper we have found a few articles relevant to the ideas proposed here. Thus Lifson, Kramlinger, Mayrand, and Lender (Gastroenterology, 1980, 79: 466-73), using microsphere injections in the living rabbit's pancreas, confirmed that blood flows from the islets to the exocrine gland and estimated that $15-21 \%$ of the pancreatic flow travelled by this route. Saito, Williams, and Kanno (J Clin Invest, 1980, 65: 777-82) using the isolated, perfused rat pancreas, showed that insulin increased both the flow of pancreatic juice and amylase release. In the case of insulinrequiring diabetics, Adrian, Barnes, and Bloom (Clin Chim Acta, 1979, 99: 213-6) found that that the plasma concentration of trypsin was about one quarter of that in normal subjects. 